\title{
Erratomycetaceae, fam. nov., and validation of some names of smut fungi recently described from India
}

\section{Cvetomir M. Denchev* \& Teodor T. Denchev}

Institute of Biodiversity and Ecosystem Research, Bulgarian Academy of Sciences, 2 Gagarin Str., Sofia 1113, Bulgaria

Received 23 November 2012 / Accepted 9 January 2013 / Published 11 January 2013

Denchev, C.M. \& Denchev, T.T. 2013. Erratomycetaceae, fam. nov., and validation of some names of smut fungi recently described from India. - Mycobiota 1: 63-70. doi: 10.12664/mycobiota.2013.01.07

\begin{abstract}
A new family, Erratomycetaceae, is described as distinct from Tilletiaceae based on host specialization, morphological features of the sori and spores, and results of published molecular phylogenetic analyses. Eight invalidly published names of Indian smut fungi are discussed. Four of these are considered to apply to distinct species and their names are validated as Eballistra punensis, Anthracocystis kolhapurensis, Sporisorium mahabaleshwarense, and Sporisorium lohagadense. The remaining names are recognized as synonyms of validly published names. A new name, Anthracocystis guode, is proposed to replace Sporisorium apludae-muticae L. Guo (non Anthracocystis apludaemuticae (A.R. Patil et al.) McTaggart \& R.G. Shivas).
\end{abstract}

Key words: Eballistra, Erratomyces, Erratomycetaceae, India, Melanotaenium, smut fungi, Sporisorium, Tilletia

\section{Introduction}

As part of an ongoing revision of Asian smut fungi, we discuss the status of some Indian species.

The genus Erratomyces (Tilletiaceae) comprises five species restricted to hosts in Fabaceae: E. patelii (Pavgi \& Thirum.) M. Piepenbr. \& R. Bauer (distributed in Africa, Brazil, Central America, the Caribbean, and India), E. ajmeriensis (J.C.S. Gupta) M. Piepenbr. \& R. Bauer (India), E. crotalariae (N.C. Joshi) M. Piepenbr. \& R. Bauer (India), E. smithiae (Thirum. et al.) M. Piepenbr. \& R. Bauer (India), and E. thirumalacharii (Pavgi) M. Piepenbr. \& R. Bauer (India) (Piepenbring \& Bauer 1997; Vánky 2011).

\footnotetext{
*Corresponding author: e-mail: cmdenchev@yahoo.co.uk
} 
Species of Erratomyces are characterized by (i) sori in leaves, forming dark spots or galls that do not rupture the epidermis; (ii) intercellular hyphae, septa with dolipores (with a pore traversed by two membranous plates; without caps); (iii) single, pigmented spores embedded in the host tissue, scattered in the intercellular spaces; and (iv) spore germination resulting in holobasidia of Tilletia-type (Piepenbring \& Bauer 1997; Vánky 2011). They have Entyloma-like sori but differ in that Entyloma species have simple septal pores with two membrane caps. The genus Erratomyces was considered to be closely related to Tilletia on the basis of morphology characters (large, pigmented spores, spore germination of Tilletia-type, intercellular hyphae) and ultrastructure (dolipore without caps, traversed by two membranous plates) (Piepenbring \& Bauer 1997; Vánky 2011) and was placed in the family Tilletiaceae (Piepenbring \& Bauer 1997; Vánky 2002).

There are five other genera in the Tilletiaceae: Tilletia, Conidiosporomyces, Ingoldiomyces, Neovossia, and Oberwinkleria, which have species that are specialized pathogens restricted to ovaries of hosts in the Poaceae. Species of Erratomyces differ from the members of these genera by host specialization on Fabaceae, and by spores embedded in the leaf mesophyll without rupturing the epidermis. As an exception, a small group of Tilletia species also form sori in leaves, but their mature sori rupture the epidermis, exposing a powdery spore mass. The need for a new family to accommodate Erratomyces, was supported by results from molecular phylogenetic analyses (Castlebury et al. 2005).

We propose Erratomyces be removed from the Tilletiaceae and placed in a new family.

Recently, a new monograph of the smut fungi in India was published by Gandhe (2011). Eight names of new species, described in that book, were not validly published under the ICN. For those names, the necessary indication of the type was not given by the word 'typus' or an equivalent (Art. 40.6). Moreover, seven of these new species were described in an inappropriate genus. Four of the species in question are distinct and the names are validly published here (Art. 33.1) to facilitate their citation in forthcoming publication.

\section{Material and methods}

For examination of Erratomyces patelii under light microscope, spores from a dried specimen were mounted in lactophenol solution on glass slides, gently heated to boiling point to rehydrate the spores, and then cooled. Spore measurements are given in the form: min-max [mean \pm 1 standard deviation].

\section{A new family for Erratomyces}

A new family is proposed to accommodate Erratomyces, based on host specialization and morphology of sori and spores, as well as on results of published molecular phylogenetic analyses (Castlebury et al. 2005). 
Erratomycetaceae Denchev \& T. Denchev, fam. nov.

\section{IF 550107}

Member of the order Tilletiales R. Bauer \& Oberw.; having intercellular hyphae, septa with dolipores without caps, traversed by two membranous plates, and the characters of the genus Erratomyces. Sori in leaves of plants of Fabaceae forming dark spots or galls that do not burst or rupture the epidermis. Spores single, pigmented, embedded in the host tissue. Spore germination in holobasidia of Tilletia-type.

Type genus: Erratomyces M. Piepenbr. \& R. Bauer, Mycologia 89: 930, 1997.

The type species of Erratomyces is characterised as follows:

Erratomyces patelii (Pavgi \& Thirum.) M. Piepenbr. \& R. Bauer, Mycologia 89: 933, 1997.

Figs $1-3$

Sori in leaves, forming polyangular spots, limited by leaf veins, 1.5-6(-9) $\mathrm{mm}$ long, larger by fusion, dark reddish brown; not bursting or rupturing the epidermis. Spores single, embedded in the leaf mesophyll, globose, subglobose or broadly ellipsoidal, sometimes slightly irregular, (20-)21.5-31 × (17-)18.5-28 (26.2 $\pm 2.5 \times 23.3 \pm 2.1) \mu \mathrm{m}(\mathrm{n}=100)$, medium to dark reddish brown; wall consisting of two layers, as seen in LM, inner layer evenly thickened, 0.8-1.8 $\mu \mathrm{m}$ thick, outer layer unevenly thickened, (1.8-)2.5-4.5(-6) $\mu \mathrm{m}$ thick, darker than the inner, ornamented with coarse warts, tuberculum-like and conicallike ornaments.

On Fabaceae: Phaseolus vulgaris L., Vigna spp.

Specimen examined - On Vigna mungo (L.) Hepper: INDIA, MADHYA PRADESH, Chhapara inter Seoni et Lakhnadon, 22²2' N, 79³5' E, 30 Aug 1998, leg. N.D. Sharma, det. K. Vánky (Vánky Ustilag. exsicc., no. 1052).

\section{Validation of four names of smut fungi}

1. Melanotaenium punense Gandhe (as 'punensis'; 2011: 154, nom. inval., Art. 40.6).

Melanotaenium proper is restricted to species on host plants in dicotyledonous families (Vánky 2002, 2011). All former species named in Melanotaenium on Poaceae were transferred to Jamesdicksonia, Eballistra or Phragmotaenium (Bauer et al. 2001; Vánky 2002).

On the legend of Fig. 8 of Plate 2.7 (where the spore germination of Melanotaenium punense was illustrated), Gandhe (2011) noted: 'terminal basidiospores with secondary blastospores'. Together with Fig. 132 of Plate 4.22 (Gandhe 2011), we can conclude that the spores of $M$. punense germinate in holobasidia with gastroid (rather than ballistic) basidiospores and apical budding of the basidiospores which is characteristic of Eballistra. The basidia, illustrated by Gandhe (2011), resemble those of E. brachiariae (Viégas) R. Bauer et al. The morphological features, as given in the original description, also seem similar with those of E. brachiariae, which is found on Brachiaria distachya, B. piligera (Urochloa piligera), B. plantaginea, Ottochloa nodosa, Panicum coloratum, Urochloa panicoides, U. trichopus (Vánky 2011). The genera Ottochloa, Urochloa, Brachiaria, and Panicum are 
members of tribe Paniceae. Melanotaenium punense was found on Themeda triandra, tribe Sacchareae (syn. Andropogoneae). As no species of Eballistra has previously been reported on Themeda (nor on a grass in the tribe Sacchareae), we consider that collection represents a new species.

Eballistra punensis Denchev \& T. Denchev, sp. nov.

IF 550108

Type on Themeda triandra Forssk. (Poaceae): INDIA, MAHARASHTRA STATE, Pune, 15 September 1975, leg. R.V. Gandhe (holotype, AMH 9364).

Latin description by Gandhe in Ustilaginales of India: 154, 2011 (as Melanotaenium punensis Gandhe); illustrations by Gandhe (op. c., Plate 2.7, Fig. 8 on p. 35, and Plate 4.22, Figs $128-132$ on p. 155).

2. Sorosporium kolhapurense Gandhe (as 'kolhapurensis'; 2011: 197, nom. inval., Art. 40.6), Sorosporium mahabaleshwarense Gandhe (as 'mahabaleshwarensis'; 2011: 199, nom. inval., Art. 40.6), Sorosporium matheranense Gandhe (as 'matheranensis'; 2011: 200, nom. inval., Art. 40.6).

Sorosporium was restricted to one species, S. saponariae F. Rudolphi, on caryophyllaceous plants (Vánky 1987, 1994). Later, Sorosporium was reduced to a synonym of Thecaphora, which has species restricted to dicotyledonous plants (Vánky 2002, 2011). The former Sorosporium species on Poaceae were transferred to Sporisorium. The proposal by Gandhe (2011) to establish three new species of Sorosporium on Poaceae is an error. A new taxonomic scheme of the Ustilago-Sporisorium-Macalpinomyces complex was recently proposed by McTaggart et al. (2012) and the circumscriptions of the genera Sporisorium and Anthracocystis were emended.

Sorosporium kolhapurense has characteristics of Anthracocystis: presence of filiform columellae (comp. Gandhe 2011: 198, Fig. 189) and spore balls (with darker outer spores), and absence of sterile cells.

Anthracocystis kolhapurensis Denchev \& T. Denchev, sp. nov.

IF 550109

Type on Apluda mutica L. (Poaceae): INDIA, MAHARASHTRA STATE, Kolhapur, 7 October 1975, leg. S.D. Patil (holotype, AMH 9369).

Latin description by Gandhe in Ustilaginales of India: 197, 2011 (as Sorosporium kolhapurensis Gandhe); illustrations by Gandhe (op. c., Plate 4.29, Figs 188-195 on p. 198).

Seven species of smut fungi are known on representatives of Apluda among which five species are members of Sporisorium s. lat. (Vánky 1997b, 2009, 2011), namely:

1) Sporisorium apludae (Syd. \& P. Syd.) L. Guo, Mycosystema 3: 76, 1990.

2) Anthracocystis guoae Denchev \& T. Denchev, nom. nov.

IF 550110 


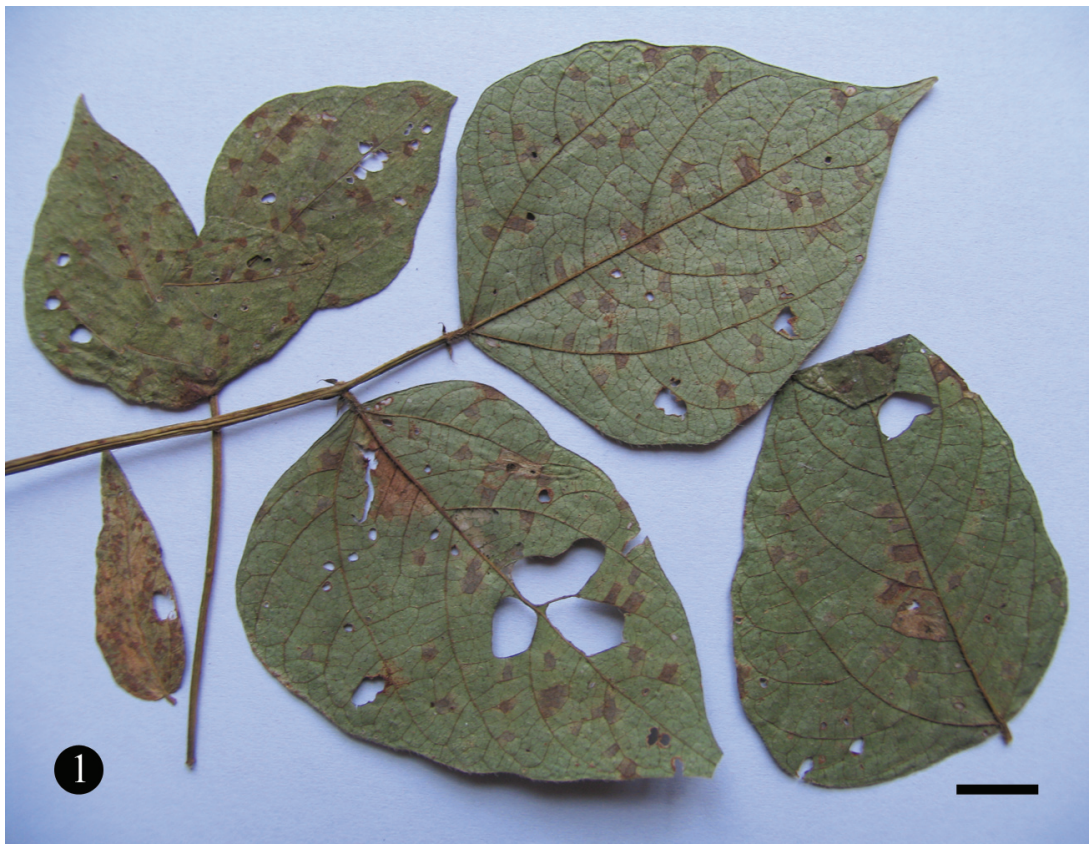

Fig. 1. Sori of Erratomyces patelii forming polyangular spots on leaves of Vigna mungo (Vánky Ustilag. exsicc., no. 1052). Habit. Scale bar $=1 \mathrm{~cm}$

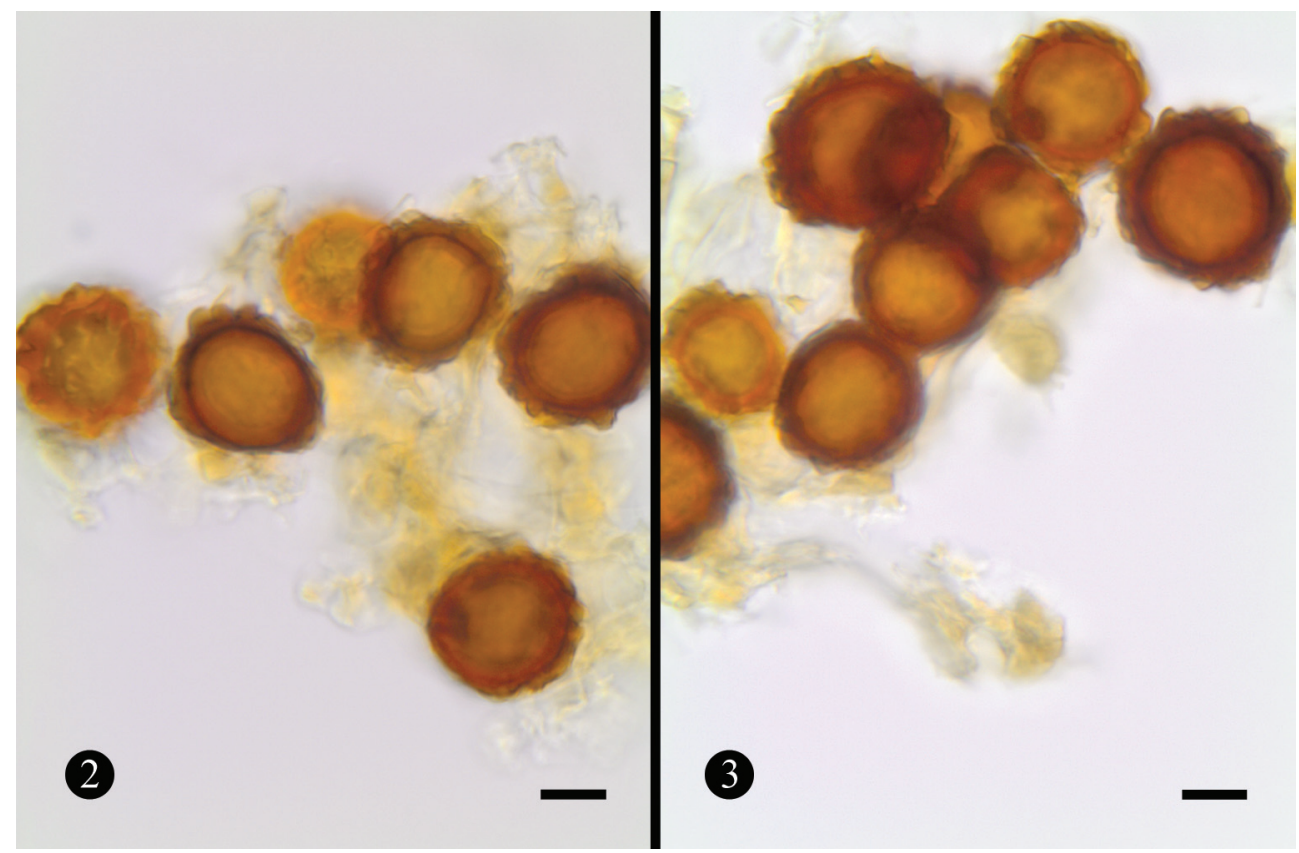

Figs 2, 3. Spores of Erratomyces patelii on Vigna mungo (Vánky Ustilag. exsicc., no. 1052) in LM. Scale bars $=10 \mu \mathrm{m}$ 
Replacing Sporisorium apludae-muticae L. Guo, Mycotaxon 72: 390, 1999 (non Anthracocystis apludae-muticae (A.R. Patil, T.M. Patil \& M.S. Patil) McTaggart \& R.G. Shivas, Persoonia 29: 120, 2012). - Type on Apluda mutica L.: CHINA, GUANGXI, Pingxiang, 6 Jan 1998, Guo L. 1622 (holotype, HMAS 77 290).

3) Anthracocystis apludae-muticae (A.R. Patil, T.M. Patil \& M.S. Patil) McTaggart \& R.G. Shivas, Persoonia 29: 120, 2012 (Syn. Sporisorium muticae Vánky \& A.R. Patil)

4) Anthracocystis apludae (Mishra) McTaggart \& R.G. Shivas, Persoonia 29: 119, 2012 (Syn. Sporisorium mishrae Vánky)

5) Anthracocystis apludae-aristatae (B.V. Patil \& Thirum.) McTaggart \& R.G. Shivas, Persoonia 29: 120, 2012.

The sori of Anthracocystis kolhapurensis are localized in spikelets and differ from those of $A$. guoae and A. apludae-muticae which destroy the whole raceme. Sporisorium apludae differs from $A$. kolhapurensis by having smaller spores (5-7 $\mu \mathrm{m}$ long) while those of the latter are 8-9.5 $\mu \mathrm{m}$ long. Anthracocystis apludae differs from $A$. kolhapurensis by the presence of sori which are grouped in the spikelets into witches' brooms. Anthracocystis apludaearistatae possesses spore balls in which the outer spores are larger $(8-12(-13) \mu \mathrm{m}$ long $)$ than those of $A$. kolhapurensis, and are in addition prominently echinulate (with spines up to 1-1.5 um high) compared to the verruculose ornamentation of $A$. kolhapurensis.

Sporisorium mahabaleshwarense Denchev \& T. Denchev, sp. nov.

\section{IF 550111}

Type on Ischaemum impressum Hack. (Poaceae): INDIA, MAHARASHTRA STATE, Mahabaleshwar, 12 October 1976, leg. R.V. Gandhe (holotype, AMH 9370).

Latin description by Gandhe in Ustilaginales of India: 199, 2011 (as Sorosporium mahabaleshwarensis Gandhe).

Based on the original description, Sporisorium mahabaleshwarense destroys the whole inflorescence transforming it into a conspicuous, cylindrical, $2-4 \mathrm{~cm}$ long sorus, at first hidden inside in the leaf sheath, and covered by a peridium. The sori possess a central, conspicuous columella, as long as the sorus, with ridges and furrows. The spore balls are irregular, loosely arranged; the spores are 11-13.5 $\mu \mathrm{m}$ long (mean $12.4 \mu \mathrm{m}$ ), 'spinulose' at the free surface; the sterile cells are 14.5-20 $\mu \mathrm{m}$ long (Gandhe 2011). Thirteen known species of Sporisorium s. lat. infect Ischaemum. There are four species of Sporisorium s. lat. that destroy the whole inflorescence (Vánky 2009, 2011). Sporisorium mahabaleshwarense can be distinguished from these species as follows. The spores of $S$. ischaemi-anthephoroides (S. Ito) Vánky \& Kakish. are very short, 5-7 $\mu \mathrm{m}$ long. The sori of Anthracocystis ischaemiana (A.R. Patil et al.) McTaggart \& R.G. Shivas (syn. S. ischaemianum) possess numerous filiform columellae. Sporisorium flagellatum (Syd., P. Syd. \& E.J. Butler) Vánky differs by having larger spores (12-19 $\mu \mathrm{m}$ long). The sori of S. ischaemi-rugosi (Mishra) Vánky possess a stout, uniform columella, with a shortly bifurcate tip, that protrudes beyond the sorus, while $S$. mahabaleshwarense has sori with a long, central, flagelliform columella with ridges and furrows. 
Sorosporium matheranense Gandhe (as 'matheranensis'), Ustilaginales of India: 200, 2011 (nom. inval.). - Type on Spodiopogon rhizophorus (Steud.) Pilg. (Poaceae), INDIA, MAHARASHTRA STATE, Matheran, 5 November 1976, leg. S.D. Patil (AMH 9371).

Sorosporium matheranense (invalidly published in the Gandhe's PhD thesis, 1978) was reduced to a synonym of Sporisorium spodiopogonis (M.S. Patil) Vánky (Vánky 1997a).

3. Sphacelotheca lohagadensis Gandhe (2011: 204, nom. inval., Art. 40.6), Sphacelotheca sinhagadensis Gandhe (2011: 207, nom. inval., Art. 40.6).

These smuts, found in inflorescences of members of the Poaceae, do not belong to the genus Sphacelotheca, species of which are restricted exclusively to Polygonaceae (see Langdon \& Fullerton 1978; Vánky 2002, 2011). They should be treated as species of Sporisorium if required.

Sporisorium lohagadense Denchev \& T. Denchev, sp. nov.

\section{IF 550112}

Type on Ischaemum tumidum Stapf (Poaceae): INDIA, MAHARASHTRA STATE, Lohagad, 5 January 1975, leg. R.V. Gandhe (holotype, AMH 9372).

Latin description by Gandhe in Ustilaginales of India: 204 \& 206, 2011 (as Sphacelotheca lohagadensis Gandhe); illustrations by Gandhe (op. c., Plate 4.30, Figs 196-199 on p. 205).

Based on the original description, Sporisorium lohagadense destroys the whole inflorescence transforming it into a cylindrical, $3-5 \mathrm{~cm}$ long sorus, at first hidden inside in the leaf sheath, covered by a peridium, with a central, branched columella, as long as the sorus. Spores are single or 'in clumps'; the spores are 8-9.5 $\mu \mathrm{m}$ long (mean $8.8 \mu \mathrm{m}$ ), smooth to finely verruculose; sterile cells are 9.5-10.5 $\mu \mathrm{m}$ long (Gandhe 2011). There are four species of Sporisorium on Ischaemum that destroy the whole inflorescence (Vánky 2009, 2011). In soral and spore characters, Sporisorium lohagadense bears some resemblance to $S$. ischaemi-anthephoroides but possesses larger spores. Anthracocystis ischaemiana is distinguished by its sori with numerous, filiform columellae. Sporisorium flagellatum and $S$. ischaemi-rugosi differ by having larger spores. Sporisorium mahabaleshwarense differs from $S$. lohagadense by having larger spores and larger sterile cells.

Sphacelotheca sinhagadensis Gandhe, Ustilaginales of India: 207, 2011 (nom. inval.). — Type on Coix lachryma-jobi L. (Poaceae), INDIA, MAHARASHTRA STATE, Pune, Sinhagad, leg. R.V. Gandhe (AMH 9373; a specimen with two gatherings, from 1 December 1975, and 5 November 1976).

Sphacelotheca sinhagadensis (invalidly published in the Gandhe's PhD thesis, 1978) was reduced to a synonym of Sporisorium lacrymae-jobi (Mundk.) Vánky (Vánky 1995).

4. Tilletia fischeri Gandhe (2011: 306, nom. inval., Art. 40.6; and later homonym, non Tilletia fischeri P. Karst., 1884) on Panicum psilopodium Trin.

Based on the original description, T. fischeri infects only some ovaries of the inflorescence, and forms sori $0.5-2.0 \mathrm{~mm}$ long. The spores are 23-26 $\mu \mathrm{m}$ long (mean 24.6 $\mu \mathrm{m})$, reticulate, with 'reticulations ... 1.6-3.2 $\mu \mathrm{m}$ broad', 'epispore rim ... 1.6-3.2 $\mu \mathrm{m}$ in 
thickness' (according to Gandhe 2011: 308). There are three species of Tilletia on Panicum with such soral characteristics and reticulate spores. The spores of T. mexicana Vánky are larger, 25-29 $\mu \mathrm{m}$ long. Whether T. fischeri is distinct from T. courtetiana Har. \& Pat. or T. narasimhanii Thirum. \& Safeeulla needs further study.

5. Ustilago tripogonis Gandhe (2011:365, nom. inval., Art. 40.6) on Tripogon lisboae Stapf and T. jacquemontii Stapf.

This species requires re-examination; it is possibly a synonym of Macalpinomyces tripogonis (M.S. Patil) Vánky, although in the protologue sterile cells were not mentioned.

Acknowledgements. The authors thank Dr Paul Kirk and the reviewers of the manuscript for their helpful and constructive comments.

\section{References}

Bauer, R., Begerow, D., Nagler, A. \& Oberwinkler, F. 2001. The Georgefischeriales: a phylogenetic hypothesis. - Mycological Research 105: 416-424.

Castlebury, L.A., Carris, L.M. \& Vánky, K. 2005. Phylogenetic analysis of Tilletia and allied genera in order Tilletiales (Ustilaginomycetes; Exobasidiomycetidae) based on large subunit nuclear rDNA sequences. - Mycologia 97: 888-900.

Gandhe, R.V. 2011. Ustilaginales of India. Bishen Singh Mahendra Pal Singh, Dehra Dun.

Langdon, R.F.N. \& Fullerton, R.A. 1978. The genus Sphacelotheca (Ustilaginales): criteria for its delimitation and the consequences thereof. - Mycotaxon 6: 421-456.

McTaggart, A.R., Shivas, R.G., Geering, A.D.W., Vánky, K. \& Scharaschkin, T. 2012. Taxonomic revision of Ustilago, Sporisorium and Macalpinomyces. - Persoonia 29: 116-132. doi: 10.3767/003158512X661462

Piepenbring, M. \& Bauer, R. 1997. Erratomyces, a new genus of Tilletiales with species on Leguminosae. - Mycologia 89: 924-936.

Vánky, K. 1987. Illustrated genera of smut fungi. Gustav Fischer Verlag, Stuttgart, New York.

Vánky, K. 1994. European smut fungi. Gustav Fischer Verlag, Stuttgart, Jena, New York.

Vánky, K. 1995. Taxonomical studies on Ustilaginales. XII. - Mycotaxon 54: 215-238.

Vánky, K. 1997a. Taxonomic studies on Ustilaginales. XV. - Mycotaxon 62: 127-150.

Vánky, K. 1997b. Taxonomic studies on Ustilaginales. XVI. - Mycotaxon 65: 133-158.

Vánky, K. 2002. Illustrated genera of smut fungi. $2^{\text {nd }}$ edn. APS Press, St. Paul, Minnesota, USA.

Vánky, K. 2009. Keys to smut fungi of selected host plant families and genera. - Mycologia Balcanica 6: 1-36.

Vánky, K. 2011('2012'). Smut fungi of the world. APS Press, St. Paul, Minnesota, USA. 